MICHA J. CZARNECKI

Instytut Politologii UMK

\title{
Człowiek wobec świata. Gnoza nowożytna Erica Voegelina a gnostycyzm antyczny - próba porównania
}

We współczesnym kryzysie prawdziwa linia podziału biegnie nie między liberałami i totalitarystami, lecz między religijnymi i filozoficznymi transcendentalistami $z$ jednej strony i liberalnymi i totalitarnymi immanentystami z drugiej strony

E R I C V O E G E L I N

Dojęcie gnozy jest jednym z centralnych zagadnień filozofii politycznej

Erica Voegelina. Próbując w swych dociekaniach określić istotę nowożytności ${ }^{1}$, niemiecki uczony odwoływał się do gnostyckich ruchów powstałych w późnej starożytności w obszarze Morza Śródziemnego i Bliskiego Wschodu jako wzoru, który - choć w zmienionej formie - zdominował intelektualną, a zatem także polityczną naturę nowożytności. Tym samym

Istotę czasów nowożytnych w kontekście zagadnień politycznych próbowano wyjaśnić m. in. poprzez zmianę sensu prawa naturalnego (Leo Strauss), odwróceniu porządku vita contemplativa i vita activa (Hannah Arendt), procesy sekularyzacji (Thomas Molnar), zdominowanie kultury umysłowej przez filozoficzny nominalizm (Richard Weaver) bądź przez kartezjański z ducha racjonalizm i empiryzm (Michael Oakeshott). 
Voegelin wpisuje się w obecną od XVIII wieku tendencję ${ }^{2}$ do opisywania czasów współczesnych z użyciem pojęcia gnozy. Również w XX wieku zainteresowanie gnozą antyczną obecne było $\mathrm{w}$ twórczości badaczy tej miary, co Wilhelm Bousset, Hans Leisegang, Hans Jonas, Gilles Quispel, Kurth Rudolph, Hans Urs von Balthazar, Jacob Taubes, Hans Soederberg; nierzadko wykorzystywano wiedzę na ten temat do lepszego zrozumienia zjawisk im współczesnych ${ }^{3}$. Bez wątpienia do pogłębionych badań nad zagadnieniem antycznego gnostycyzmu przyczyniły się odkrycia z początku XX. wieku manichejskich pism w Turfan w chińskim Turkmenistanie, odkopanie w 1930 roku części koptyjskiej biblioteki manichejskiej w Fajum, bogate znaleziska nad Morzem Martwym w Palestynie oraz nade wszystko odkrycie w 1945 roku tzw. Biblioteki z Nag Hammadi w Egipcie (starożytny Chenoboskion ${ }^{4}$ ) zawierającej potężny zbiór gnostyckich pism.

Koncepcja „gnozy - istoty nowożytności” w twórczości Voegelina zajmuje nie tylko jedno z centralnych miejsc, jest także jednym z najbardziej krytykowanych elementów filozofii politycznej tego autora ${ }^{5}$. Jest to spowodowane w dużej mierze „chłonnością” koncepcji Voegelina, który jak zauważa Ryszard Skarżyński - „do grupy gnostyków nie zaliczał jedynie zwykłych rewolucjonistów, ale po prostu wszystkich myślicieli nie będących

\footnotetext{
${ }^{2}$ Główne prace $\mathrm{z}$ tego okresu: Johann Lorenz von Mosheim, Versuch einer unparteiischen und gründlichen Ketzergeschichte, Helmstedt 1746; Johann August Neander, Genetische Entwicklung der vornehmsten gnostischen Systeme, Berlin 1818; Ferdinand Christian Baur, Die christliche Gnosis, oder die Religionsphilosophie in ihrer geschichtlichen Entwicklung, Tübingen 1835; Jacques Matter, Histoire critique du Gnosticisme et de son influence sur les sectes religieuses et philosophiques des six premiers siècles de l'ère chrétienn; Adolf von Harnack, Lehrbuch der Dogmengeschichte, Freiburg 1890. Zob. E. Voegelin, Science, Politics, and Gnosticism, Columbia 2000, s. 250-252.; Kurt Rudolph, Gnoza, przeł. G. Sowiński, Kraków 2003, s. 39-43.

${ }^{3} \mathrm{Z}$ naszego punktu widzenia szczególnie interesujące jest porównanie współczesnego egzystencjalizmu i nihilizmu z gnozą antyczną dokonaną przez Hansa Jonasa. Patrz: Hans Jonas, Religia gnozy, Kraków 1994, s. 337-358. Jako gnozę interpretował twórczość Ernesta Blocha Leszek Kołakowski (L. Kołakowski, Ernst Bloch - marksizm jako gnoza futurystyczna, w: Główne nurty marksizmu, Poznań 2001, T. III, s. 493-526); według Alaina Besancona dwudziestowieczny komunizm był gnozą polityczną (A. Besancon, Intelektualne źródła leninizmu, Paryż 1988). Istnieją także inne współczesne zjawiska interpretowane jako neognostyckie, m.in. antropozofia R. Stirnera, psychologia C.G. Junga, gnostyckie nurty we współczesnej fizyce (tzw. neognoza z Princeton), twórczość E. Ciorana, środowiska różokrzyżowców.

${ }^{4}$ Hans Jonas, dz.cyt., s. 307-308.

${ }_{5}^{5}$ Patrz: R. Skarżyński, Koncepcja gnozy Erica Voegelina, w: Gnoza polityczna, J. Skoczyński (red.), Kraków 1998, s. 29-37; P. Skudrzyk, Gnoza - nieudana determinacja. Refleksje nad Nowa nauka polityki Erica Voegelina, tamże, s. 53-60; R. Skarżyński, Konserwatyzm: zarys dziejów filozofii politycznej, Warszawa 1998, s. 253-257; A. Wielomski, Filozofia polityczna Erica Voegelina, „Arcana” nr 29, 1999, s. 134-155; M. Zimniak-Hałajko, J. Hałajko, Przygody gnozy według Erica Voegelina, „Przegląd Filozoficzny”, nr 2, 2003, s. 89-100; I.P. Cauliano, Gnostycyzm jako wzorzec analogiczny, ,Znak”, nr 7, 1991, s. 40-53.
} 
kontynuatorami właściwej tradycji" ${ }^{6}$. Tym samym do gnostyckiego bestiariusza autora Order nad History wpisuje się cała plejada nowożytnych autorów: Niccolo Machiavelli, Thomas Hobbes, francuscy les philosophes, Georg Hegel, August Comte, Karl Marks, Georges Sorel, Michaił Bakunin, Friedrich Nietzsche czy Martin Heidegger. Stąd rodzą się dwie zasadnicze wątpliwości dotyczące wartości tej koncepcji. Przede wszystkim należy rozpatrzyć kwestię, czy koncepcja gnozy stworzona przez Voegelina - tak obszerna, obejmująca wiele nurtów i konkretnych myślicieli nowożytności $-\mathrm{z}$ naukowego punktu jest kategorią użyteczną, czy ma moc dystynktywną, co z kolei prowadzi nas do pytania o jej relacje z gnozą starożytną i to, czy posługiwanie się tą kategorią przez Voegelina jest w pełni uzasadnione. W niniejszym artykule - chcąc odpowiedzieć na powyższe pytania - spróbuję przedstawić gnostycki syndrom nowożytności Erica Voegelina, zestawiając go z gnozą antyczną, jej istotą i symboliką w ujęciu przedstawionym przez jednego z najwybitniejszych XX-wiecznych badaczy tego zjawiska - Hansa Jonasa ${ }^{7}$. Analizy dokonam $\mathrm{w}$ aspekcie związków na poziomie esencjonalnym (istotowym, substancjalnym), mniej uwagi poświęcając związkom genetycznym.

Zanim przejdę do sedna sprawy, słowo o kwestiach terminologicznych, które w kontekście gnozy stanowią przedmiot licznych kontrowersji i dyskusji. W niniejszym artykule będę trzymał się akceptowanych powszechnie ustaleń dokonanych podczas kongresu w Messynie z 1966 roku poświęconego zagadnieniom gnozy i gnostycyzmu. Zgromadzona tam komisja badaczy ustaliła, iż przez gnostycyzm należy rozumieć określoną grupe systemów z II wieku po Chrystusie, natomiast - w przeciwieństwie do niego - przez gnozę rozumie się „wiedzę o boskich tajemnicach, zastrzeżoną dla pewnej elity”. Stąd „typ gnozy, o który chodzi w gnostycyzmie, podlega następującym warunkom ontologicznym, teologicznym i antropologicznym: nie każda gnoza jest gnostycyzmem, lecz jedynie ta, która w tym kontekście zawiera wyobrażenie identyczności natury boskości z (boską) iskrą (w duszy ludzkiej), która ma zostać ponownie ożywiona i przywrócona do dawnego

\footnotetext{
${ }^{6}$ R. Skarżyński, Koncepcja gnozy..., s. 30; „(...) definicję proponowaną przez Voegelina można chyba uznać za najszerszą z dotychczas stworzonych" (M. Zimniak-Hałajko, J. Hałajko, dz.cyt. s. 92). Sam Voegelin wprost stwierdza: „By gnostic movements we mean such movements as progressivism, positivism, Marxism, psychoanalysis, communism, fascism, and national socialism" (E. Voegelin, Science, Politics, and Gnosticism, w: The Collected Works of Eric Voegelin, Columbia 2000, s. 295.).

${ }^{7}$ Fundamentalną pracą Hansa Jonasa w tym zakresie jest dwutomowe dzieło Gnosis und spätantiker Geist, (1934). W niniejszym artykule opieram się na innej pracy Religia gnozy z 1958, które stanowi syntezę ujęcia Jonasa.

${ }^{8}$ Le Origini delio Gnosticismo. Colloquio di Messina 13-18 Aprille 1966, Leiden 1967, s. XX-XXXII, cyt. za: Jerzy Prokopiuk, Gnoza i gnostycyzm, dostępne: http://gnosis.art.pl/prokopiuk_gnoza_i_ gnostycyzm01.htm [15.09.2007].
} 
stanu"9. W związku z powyższym otwartą pozostaje kwestia gnozy jako istoty nowożytności, której poświęcony jest ten artykuł.

\section{Gnostycyzm starożytny w ujęciu Hansa Jonasa}

Dorobek badań na gnostycyzmem starożytnym ukazuje nam niezwykłe bogactwo systemów doktrynalnych powstałych w okresie wczesnego chrześcijaństwa (I-III wiek n.e.). Najważniejsze z nich: szkoły Szymona Maga, Bazylidesa, Marcjona, Walentyna, Maniego ${ }^{10}$ ukazują nie tylko rozmaitość tych doktryn, ale także ich wzajemną odrębność. Opisując ten barwny wachlarz, Hans Jonas konstatuje jednak, iż „bez względu na to, jakie wyżyny konceptualizacji gnostyckiej teorii osiągnęli indywidualni myśliciele, istnieje niezaprzeczalne jądro w gnostyckiej myśli jako takiej" ${ }^{11}$. Opis natury jądra gnostycyzmu niemiecki uczony sporządził podług pięciu zasadniczych kategorii: stosunku gnostyków do transcendencji, do świata, do człowieka, do kwestii eschatologicznych oraz do moralności i prawa, wyróżniając przy tym wspólną wszystkim nurtom symbolikę.

Zasadniczą kategorią określającą stanowiska gnostyckie jest dualizm. Objawia się on przede wszystkim w relacjach człowieka ze światem przedstawianym jako królestwo ciemności, więzienie człowieka rządzone przez Archontów. Drugim wymiarem gnostyckiego dualizmu jest relacja Boga, który stanowi królestwo światłości, ze światem. Bóg jest dla człowieka ukryty, jego poznanie wymaga objawienia i iluminacji ${ }^{12}$. Sam świat nie jest bynajmniej dziełem Boga, lecz Archontów ${ }^{13}$, panów poszczególnych kręgów wszechświata $^{14}$. Widoczne jest tu kluczowe dla całego gnostycyzmu przekonanie o wyobcowaniu człowieka, które można rozpatrywać w dwojakim wymiarze ${ }^{15}$ : pozytywnym, który obrazuje wyższość względem ziem-

\footnotetext{
${ }^{9}$ Tamże.

${ }^{10}$ Zob. K. Rudolph, dz.cyt., s. 290-254.

${ }^{11}$ H. Jonas, dz.cyt., s. 62.

${ }^{12}$ Tamże, s. 58.

${ }^{13}$ Czasem - jak pisze Jonas - jest to Demiurg jako przywódca Archontów (Tamże, s. 59).

${ }^{14}$ „Najczęściej jest to siedem sfer planetarnych otoczone przez ósmą, na której utwierdzone są gwiazdy. Istniała tendencja do mnożenia struktur i tworzenia coraz bardziej rozbudowanego układu: Bazylides doliczył się nie mniej niż 365 «niebios». Religijna doniosłość tej kosmicznej architektury zasadza się na idei, że wszystko, co wkracza pomiędzy to, co tutaj a to, co ponad, służy oddzieleniu człowieka od Boga nie tylko w sensie przestrzennym, ale w sensie działania aktywnej siły demonicznej" (Tamże, s. 59).

15 „Pamięć o własnej obcości, rozpoznanie świata jako miejsca wygnania, stanowi pierwszy krok w odwrotnym kierunku; przebudzona tęsknota za ojczyną to początek powrotu. (...) Jednakże z uwagi na jej pochodzenie jest ona zarazem znakiem wyższości, źródłem mocy nieznanego otoczeniu ukrytego życia, a w ostatecznym rachunku jest ona odporna na wpływ otoczenia, tak jak jest niepojęta dla stworzeń tego świata" (Tamże, s. 65).
} 
skiego otoczenia oraz negatywnym znamionującym cierpienie wynikłe z losu, oddalenia od Boga i osadzenia w ziemskim królestwie Archontów ${ }^{16}$. Z obrazu „obcości” wynikają inne symbole określające kondycję człowieka w kontekście teologicznym i kosmologicznym. Rodzą się opozycje: „te światy”-,tamten świat”, „wielość”-,,jedność”. Czasowy i przestrzenny charakter „kosmicznej trwogi” znamionuje oddalenie człowieka od Boga. Ziemskie bytowanie istoty ludzkiej określane jest więc terminami podkreślającymi jego tymczasowość i prowizoryczność - pobyt w świecie jest „mieszkaniem”, „domem śmierci”, ciało człowieka „domem”, „szatą” bądź „namiotem”"17.

Drugą kluczową kwestią jest gnostycka antropologia zakładająca zasadniczy podział człowieka na ciało (soma), duszę (psyche) oraz ducha (pneuma). Te składniki odpowiadają dwóm źródłom pochodzenia człowieka, które - mówiąc językiem Carla Schmitta - wyznaczają jego egzystencjalną sytuację. Z jednej strony człowiek określany jest w wymiarze światowym, do którego należy dusza i ciało, ukształtowane na wzór Człowieka Idealnego (Praczłowieka) za pomocą własnych sił psychicznych: żądzy i namiętności, które wszystkie razem tworzą duszę człowieka. Tą drogą kształtuje się ziemska, ergo: ta zła, strona każdego człowieka, który poprzez ciało i duszę podlega heimarmene ${ }^{18}$. Drugi wymiar, który określa pochodzenie (a zatem i powołanie) człowieka ma charakter pozaświatowy. Stanowi o tym pneuma, jaźń - w przekonaniu gnostyków boska cząstka uwięziona przez Archontów w człowieku cielesnym, spętana przy tym przez duchowe żądze. Człowiek W wizji gnostyckiej znajduje się w stanie upadku ${ }^{19}$, „uwięzienia”, ,odrętwienia”, „uśpienia”. W tej perspektywie powołanie człowieka sprowadza się do przebudzenia pneumy, uświadomienia sobie jej obecności. Może to się dokonać dzięki „wiedzy” (gnosis), która automatycznie prowadzi do wyzwolenia i odkupienia pneumy, dotarcia do Absolutu ${ }^{20}$. Jak obrazowo pisze Jonas „wyposażona w taką gnozę $e^{21}$, dusza wędruje po śmierci w górę ${ }^{22}$, pozostawia-

\footnotetext{
${ }^{16}$ Tamże, s. 64-66.

${ }^{17}$ Tamże, s. 66-71.

${ }^{18} \mathrm{~W}$ gnostyckiej symbolice heimarnene oznacza powszechny los; fakt tyrańskich rządów Archontów, którym poddany jest człowiek (Patrz: H. Jonas, dz.cyt. s. 59-60).

${ }^{19}$ Jak pisze Jonas: „Upadek miał miejsce przed powstaniem kosmosu, zaś do jego konsekwencji należy samo stworzenie świata a także kondycja i los indywidualnych dusz w świecie" (Tamże, s. 77). Oznacza to, że człowiek nie jest winien swego upadku; jego sytuację egzystencjalną określa tajemnicze „wrzucenie w świat”. Stwórca świata jest odpowiedzialny za zło.

${ }^{20}$ Tamże, s. 60.

${ }^{21}$ Wiedza ta dotyczy transcendentnego Boga i człowieka; określa boski rodowód człowieka oraz naturę świata, która determinuje ziemską sytuację rodzaju ludzkiego (H. Jonas, dz.cyt. 61).
} 
jąc za sobą w każdej sferze pochodzącą z niej psychiczną 'szatę’: pozbywszy się w ten sposób wszelkich obcych narośli, duch dociera do transcendentnego Boga i jednoczy się na nowo z Boską substancją"23. W realizacji tego eschatologicznego wymiaru w gnostyckich systemach ważną rolę odgrywa zwiastun - „posłaniec ze świata światłości, który przenika granice sfer, przechytrza Archontów, budzi ludzi z jego ziemskiej drzemki i udziela mu zbawczej wiedzy z 'tamtej strony' "24. Odpowiedzią na wezwanie jest z jednej strony przerażenie i lament nad prawdziwym obrazem własnej egzystencji, z drugiej zaś - co jest niezwykle charakterystyczne dla systemów gnostyckich - pretensja, oskarżenie „Wielkiego Życia” 25 , wezwanie aby wytłumaczyło się z istnienia świata i uwięzienia tam człowieka (pneumy) ${ }^{26}$.

Niezwykle wymowny w tym kontekście jest buntowniczy ton alegorii obecnych w systemach gnostyckich, który jest zdaniem Jonasa "jednym z wyznaczników rewolucyjnego stanowiska jakie w późnej kulturze antycznej zajmują gnostycy" ${ }^{27}$. W książce Religia gnozy prezentuje on najbardziej reprezentatywne i brzemienne $\mathrm{w}$ skutki pary alegorii stworzone przez gnostyków: Ewy i Węża (oraz Jezusa jako personifikacji „węża uniwersalnego"), Kaina (duchowy symbol; prototyp wygnańca skazanego przez Boga na bycie zbiegiem i włóczęgą na ziemi) i Stwórcy (mroczny i żądny krwi bóg) oraz Prometeusza (wierny nie bogu tego świata, czyli nie Zeusowi, ale bogu go przekraczającemu) i Zeusa ${ }^{28}$.

Wszystko to rzutuje również na stosunek gnostyków do moralności i prawa. Jonas wyróżniając dwa warianty tej relacji: libertyński i ascetyczny, stwierdza, iż oba cechuje głęboki nihilizm. Wyrasta on z przekonania gnostyków o automatycznym i niezbywalnym zbawieniu pneumy oraz z antynomicznego przeświadczenia, iż prawo i moralność są jednymi z rodzajów kosmicznej tyrani obowiązującej ciała i dusze. Można więc powiedzieć, że jest to swoisty amoralizm. Stąd właśnie bierze się wyraźny podział w gnostyckich systemach na pneumatyków, czyli tych, którzy posiadają wiedzę (gnozę), oraz resztę tj. psychików, posiadających tylko duszę, jednako zdolną

\footnotetext{
${ }^{22}$ Pozornie owa droga w górę jest tożsama z niezwykle ważną - co podkreślał sam Voegelin w swym fundamentalnym dziele Order and History - platońską symboliką podróży duszy w dół i w górę. Dualizm grecki (w tym platoński) ma jednak prokosmiczny charakter natomiast gnostycyzm zdecydowanie antykosmiczny, co wyklucza tę tożsamość. Patrz: M. Ruba, Światopoglad gnostycki, „Znak” nr 4, 1996, s. 78.

${ }^{23}$ H. Jonas, dz.cyt., s. 61. Wskazuje to wyraźnie, na swoiście panteistyczny rys gnostycyzmu.

${ }^{24}$ Tamże

${ }^{25}$ Tamże.

${ }^{26}$ Tamże, s. 100-104.

${ }^{27}$ Tamże, s. 105.

${ }^{28}$ Tamże, s. 106-111.
} 
do przyjęcia boskiego ducha - pneumy i hylików/choików, których wymiar życiowy zamyka się $\mathrm{w}$ horyzoncie ziemskim ${ }^{29}$. Moralność gnostycka charakteryzuje się zatem pogardą dla światowych więzi owocującą ascetycznym wycofaniem bądź libertyńskim aktywizmem gardzącym wszystkim, co światowe ${ }^{30}$

\section{Koncepcja gnozy jako istoty nowożytności Erica Voegelina}

W swoich badaniach nad gnostycyzmem Voegelin wyróżnia sześć zasadniczych symptomów, które pozwalają nakreślić psychologiczny kontekst tego zjawiska. Po pierwsze, gnostyk nie jest zadowolony ze swego położenia; po drugie, w takiej sytuacji egzystencjalnej towarzyszy mu przekonanie, że owo niezadowolenie wynika ze złej natury tego świata. Odrzuca więc a priori, że zło w świecie jest rezultatem grzesznej, niedoskonałej natury człowieka, a przyjmuje, że zły jest świat, w którym człowiek żyje. Po trzecie, wierzy w wybawienie od zła tego świata; po czwarte - jest przekonany, iż efektem owego wybawienia musi być powstanie dobrego świata. Powstanie to odbędzie się w procesie historycznym dzięki - i to jest piąty par excellance gnostycki symptom - wierze, że człowiek jest zdolny własnymi siłami, samodzielnie „dokonać przeobrażenia porządku bytów”; po szóste: gnostyk, rozpoznając w sobie potencję do takiej przemiany konstruuje receptę na zbawienie zarówno świata jak i siebie. Gnostyk jest więc według Voegelina prorokiem głoszącym swoja wiedzę o zbawieniu rodzaju ludzkiego ${ }^{31}$.

Zdaniem Voegelina współczesne masowe nurty gnostyckie w celu wyodrębnienia swojego stanowiska mają skłonność do wykształcania rozbudowanej symboliki o właściwym sobie charakterze. W pracach poświeconych gnostycyzmowi ${ }^{32}$ opisuje podstawowy, a zarazem najważniejszy katalog symboli występujących w tych ruchach.

Pierwszą grupę symboliczną tworzą wariacje na temat chrześcijańskiej idei doskonałości, w obrębie której - zdaniem autora tego rozróżnienia Ernsta Troeltscha - istnieją dwa wymiary: teleologiczny (skierowany na cel ostatecznego spełnienia) oraz aksjologiczny (zaakcentowanie celu, telos, jako

\footnotetext{
${ }^{29}$ K. Matys, Elitaryzm gnostycki. Próba refleksji nad gnostycyzmem antycznym, w: Oblicza gnozy, E. Przybył (red.), Kraków 2000, s. 58.

${ }^{30}$ H. Jonas, dz.cyt., s. 61.

${ }^{31}$ E. Voegelin, Science... s. 296-298.

${ }^{32}$ Kwestię istoty gnozy Voegelin poruszał głównie w następujących pracach: E. Voegelin, Science, Politics, and Gnosticism, Columbia 2000; Tenże, Nowa nauka polityki, przeł. P. Śpiewak, Warszawa 1992; Tenże, Gnostic Politics, w: The Collected Works of Eric Voegelin, Columbia T. X, s. 223-240; Tenże, Lud Boży, przeł. M. Umińska, Kraków 1994.
} 
stanu wyższej wartości). Voegelin przedstawia trzy zasadnicze możliwości wyrosłe z tego rozróżnienia, trzy typy immanentyzacji idei zbawienia. Na bazie zapożyczenia aksjologicznego ufundowany jest utopizm (np. Utopia Tomasza Morusa), który, koncentrując się na szczegółowym kreśleniu pożądanego obrazu świata, nie wspomina w ogóle lub wspomina w niewielkim stopniu o metodach osiągnięcia tego stanu. Drugim jest progresywizm powstały na zapożyczeniu teleologicznym, charakterystyczny szczególnie dla rozwijającej się w XVIII wieku idei postępu (Kant, Condorcet). Progresywizm - przeciwnie niż utopizm - koncentruje się na zimmanentyzowanym pragnieniu osiągnięcia stanu doskonałości umiejscowionego w bliżej nieokreślonej przyszłości. Areną osiągania tego stanu ma być historia, zaś metodą - deterministycznie nacechowana idea postępu. Natomiast trzecim typem przekształcenia symboliki chrześcijańskiego zbawienia jest aktywistyczna mistyka, która wynika ze zmieszania składników aksjologicznego i teleologicznego. Łącząc $w$ sobie naturę dwóch powyższych komponentów przedstawia zarówno obraz celu tj. idealnego społeczeństwa oraz receptę na jego osiągnięcie. To połączenie zdaniem Voegelina występuje w ruchach wywodzących się od Augusta Comte'a oraz Karola Marksa ${ }^{33}$.

Kolejny zespół gnostyckiej symboliki charakterystycznej dla czasów nowożytnych swój rodowód zawdzięcza twórczości żyjącego w XII wieku Joachima z Fiore ${ }^{34}$. Ów średniowieczny mnich i kaznodzieja, którego twórczości Voegelin przypisuje zasadniczą rolę w określeniu charakteru nowożytnej gnozy, swoje historyczne spekulacje oparł na bogatej symbolice, która odtąd stała się obecna w ruchach masowych o gnostyckim charakterze. Te symbole to kolejno: idea Trzeciego Królestwa, symbol wodza (dux), symbol zwiastuna oraz symbol uduchowionej wspólnoty ${ }^{35}$.

Idea Trzeciego Królestwa zakłada trynitarną wizję dziejów, w której trzecia faza będzie stanem ostatecznej doskonałości. Jest to zdaniem Voegelina naczelny element symboliczny inspirujący prądy intelektualne, które zdominowały nowożytność oraz szereg rewolucji i totalitarnych systemów w obszarze życia społecznego i politycznego. U Joachima doskonałość będąca

\footnotetext{
${ }^{33}$ E. Voegelin, Science..., s. 298-300.

${ }^{34} \mathrm{Na}$ temat postaci Joachima i jego oddziaływania patrz: J. Grzeszczak, Od epoki Ducha Świętego do ery Wodnika. Oblicza duchowego dziedzictwa Joachima z Fiore, w: Sapientis est ordinare. Opuscula Ludvico Wciórka septuagenario dedicata, F. Lenort (red.), Poznań 2001, s. 59-71; Tenże, Joachim z Fiore. Średniowieczny przyczynek do teologii dziejów, Poznań 2006; K. Löwith, Historia powszechna $i$ dzieje zbawienia, Kęty 2002, s. 141-153; M. Figura, Duchowe dziedzictwo Joachima $z$ Fiore $w$ interpretacji Henri de Lubaca, „Communio” nr 4, 2000, s. 66-86.

${ }^{35}$ Tamże, s. 300-301.
} 
wyrazem nastania epoki Ducha ${ }^{36}$ miała - jak pisze Voegelin - charakter antyinstytucjonalny ${ }^{37}$. Ulegając procesowi stopniowej sekularyzacji, trynitarna symbolika osiągnęła kulminację $\mathrm{w}$ dziewiętnastowiecznej interpretacji dziejów dokonanej przez Marksa (faza pierwotnego komunizmu, burżuazyjnego społeczeństwa klasowego oraz komunistycznego społeczeństwa bezklasowego). W swych pismach Voegelin jako przykłady trynitarynych spekulacji dotyczących dziejów wymienia również humanistyczny podział Bionda (na starożytność, średniowiecze oraz nowożytność), zasadę trzech faz Turgota i Comte'a ${ }^{38}$ (faza teologiczna, metafizyczna oraz pozytywna), podział dziejów świata podług kryterium wolności Hegla (starożytny despotyzm orientalny, czas arystokracji, gdzie wolni byli nieliczni oraz czasy nowożytne, gdzie wszyscy są wolni) oraz Schellinga (trzy zasadnicze fazy chrześcijaństwa: Piotrową, Pawłową oraz Janową) $)^{39}$.

Kolejny symbol - wódz, jest ściśle związany z poprzednim, niejako wynikając z niego. Każda epoka w trynitarnej koncepcji Joachima z Fiore inaugurowana jest przez postać, która przez swoje objawienie rozpoczyna nową erę: epoka Ojca zainaugurowana była pojawieniem się Abrahama, epoka Syna pojawieniem się Chrystusa, natomiast trzecia epoka - epoka Ducha ${ }^{40}$ rozpocznie się wraz z pojawieniem się Dux e Babylone. Także w obrębie tego symbolu mamy do czynienia z ewolucją od charakteru religijnego w kierunku jego zsekularyzowanej postaci. Już w czasach Joachima ten symbol był na tyle popularny, iż posługiwał się nim w swych spekulacjach Dante. Czaru tej symboliki doświadczył również żyjący w tym samym czasie założyciel zakonu franciszkanów św. Franciszek z Asyżu - brany przez wielu za uosobienie wodza trzeciej epoki ${ }^{41}$. W kolejnych wiekach - jak pisze Voegelin - ta symbolika uobecniała się w heterodoksyjnych ruchach religijnych reformacji na czele z jej wodzami, parakletami kierowanymi przez Ducha Bożego ${ }^{42}$.

\footnotetext{
${ }^{36}$ Poprzedzały ją epoka Ojca, która trwała do czasu przyjścia Chrystusa, kiedy to rozpoczęła się epoka Syna (E. Voegelin, Nowa nauka..., s.106).

37 "In our context, the importance of this image lies in the idea of a spiritualized mankind existing in community without the mediation and support of institutions; for, according to Joachim's view, the spiritual community of monks was to exist without the sacramental supports of the Church" (E. Voegelin, Science...., s. 304).

${ }^{38}$ Comte'owska koncepcja trzech faz rozwoju społeczeństw została zaczerpnięta od SaintSimona, którego Comte był przez długi czas sekretarzem. Por. J. Szacki, Historia myśli socjologicznej, Warszawa 2005, s. 161-168, 251-263.

${ }^{39}$ E. Voegelin, Science..., s. 301-302.

${ }^{40} \mathrm{~W}$ spekulacji Joachima wypełnienie się epoki Syna i zarazem nastanie epoki Ducha datowane jest na rok 1260.

${ }^{41}$ Patrz. G. Duby, Czasy katedr. Sztuka i społeczeństwo 980-1420, Warszawa 1986, s. 269.

${ }^{42}$ Patrz: E. Voegelin, Rewolucja gnostycka - przypadek purytanów, w: Nowa..., s. 125-147; Tenże, Gnostic Politics, Columbia 2000, s. 223-240; Tenże, Lud Boży, s. 64-73.
} 
W XVIII i XIX wieku symbolika ta znalazła wyraz w idei nadczłowieka obywatela Trzeciego Królestwa i zarazem jego herolda - obecnej u Condorceta (typ nadczłowieka progresywnego), Comte'a (pozytywistycznego), Marksa (komunistycznego) oraz Nietzschego (dionizyjskiego). Myśliciele ci i ich koncepcje w sposób znaczący zaważyli na głównych wydarzeniach i sposobie postrzegania dwudziestowiecznej polityki, zarówno w kontekście totalitarnych ruchów masowych, jak i demokracji liberalnej ${ }^{43}$.

Trzeci typ symboliczny - zwiastun poprzedzający nadejście wodza w spekulacji Joachima odwołuje się do postaci Jana Chrzciciela jako poprzednika Chrystusa; sam Joachim przypisywał sobie rolę zwiastuna epoki Ducha. Symbolika ta na przestrzeni wieków znalazła swój wyraz w intelektualiście cechującym się profetycznymi zdolnościami w zakresie odczytywania eidiosu dziejów, a więc i znającym receptę na wyzwolenie świata ze stanu $\mathrm{zła}^{44}$. Uosobienie tej symboliki autor Nowej nauki polityki widzi również w osobach Marksa i Comte'a, których koncepcje prognozują ziszczenie się doskonałych stosunków międzyludzkich w postaci nowej wspólnoty, która jest czwartym z kolei wyróżnionym przez Voegelina symbolem wyrosłym z pnia koncepcji Joachima z Fiore. W spekulacjach kalabryjskiego mnicha Trzecie Królestwo zrealizuje się w swoiście rozumianej wspólnocie mnichów, której wymiar duchowy istniałby bez instytucjonalnego wsparcia Kościoła. Zdaniem Voegelina echa tego pragnienia widoczne są we współczesnych ruchach masowych rozmaitych odcieni, które swą inspirację czerpią od koncepcji przywołanych tu dziewiętnastowiecznych myślicieli, gdzie symbolika joachimowej wspólnoty mnichów uobecnia się pod postacią pragnienia uśmiercenia (komunizm) bądź radykalnego ograniczenia państwa i jego instytucji (liberalizm) ${ }^{45}$.

\section{Konkluzje}

Powyższa prezentacja istoty gnostycyzmu oraz gnostyckiego syndromu charakterystycznego dla nowożytności, pozwala na ogólną konkluzję dotyczącą podobieństw tych dwóch zjawisk. Nade wszystko należy stwierdzić, iż w obu ujęciach występuje zasadnicza cecha przynależna gnostycyzmowi $^{46}$ tj. silnie zarysowany dualizm świat - człowiek; sytuację egzysten-

\footnotetext{
${ }^{43}$ Patrz: E. Voegelin, Word Empire and Unity of Mankind, "International Affairs", nr 2, 1962, s. 170 188.

${ }^{44}$ Por. P. Johnson, Intelektualiści, Warszawa 1994, szczególnie rozdziały I, III, VIII, IX poświęcone kolejno sylwetkom J.J. Rousseau, K. Marksa, B. Russella oraz J.P. Sartre'a.

${ }^{45}$ E. Voegelin, Science..., s. 303-304.

${ }^{46} \mathrm{Na}$ fundamentalne znaczenie dualizmu (a nie chociażby skłonność do spekulacji dotyczących wyższych światów czy samej wiedzy-gnozy) w kontekście istoty gnostycyzmu wskazuje Hans Jonas oraz Jean Danielou (cyt. za: K. Dorosz, Przeciw gnostykom, Paryż 1989, s. 199).
} 
cjalną człowieka cechuje obcość wobec świata, który jest źródłem zła, a jego stan powoduje niezadowolenie człowieka ze swego położenia. Towarzyszy temu z drugiej strony sytuowanie w człowieku źródła dobra, już to w formie iskry bożej (pneumy) w gnostycyzmie, czy w koncepcjach nadczłowieka, woli mocy czy libido dominandi, czyli wiary w zdolność człowieka w zapanowaniu nad naturą, swoim życiem oraz historią. Ascetyczne bądź libertyńskie inklinacje gnostycyzmu ${ }^{47}$, obecne już w rygoryzmie purytanów z XVII wieku znajdowały wyraz we wszystkich późniejszych wielkich rewolucjach nowożytności: francuskiej, rosyjskiej oraz rewolucji przemysłowej, które swoje zaistnienie zawdzięczają wymienianym tu już wielokrotnie autorom klasyfikowanym przez Voegelina jako gnostycy. Również na poziomie symbolicznym odnajdujemy znaczące zbieżności. Poza wspomnianym już motywem wyobcowania powtarza się także postać wodza-zwiastuna, jako pozytywna transfiguracja motywu prometejskiego, buntownika walczącego w imię ludzkości przeciw bogom tego świata.

Nie sposób zaprzeczyć, iż poza wymienionymi tu zasadniczymi podobieństwami istnieje również istotna różnica. W przeciwieństwie do starożytnego gnostycyzmu z pierwszych wieków po Chrystusie, gnostycki symptom nowożytności charakteryzuje nieobecność kwestii transcendencji. Systemy Walentyna, Marcjona czy Bazylidesa i im pokrewne, choć miały wymiar zgoła filozoficzny, a nie religijny ${ }^{48}$, cechowała przede wszystkim swoista koncentracja na zagadnieniach transcendencji i stosunku do Boga pozaświatowego. Wyróżniająca się postępującym sekularyzmem epoka nowożytna, pozbawiła również tendencje gnostyckie w kulturze europejskiej transcendentnego wymiaru poprzez zimmanentyzowanie pragnienia ucieczki w rzeczywistość doskonałą owocujące projektami utopistycznymi, progresywistycznymi bądź aktywizmu mistycznego. Pragnienie ucieczki spowodowane jest zdaniem Voegelina przez rodzące się poczucie niepewności i zagubienia wywołane przez chrześcijańskie odbóstwienie świata. Ortodoksja chrześcijańska budowała swój stosunek do rzeczywistości w oparciu o „kompromisy ze światem" 49 wykluczające panteistyczne tendencje obecne w mitologii

\footnotetext{
${ }^{47}$ „Warto podkreślić, że skrajna asceza gnostyków nie ma nic wspólnego z ascezą chrześcijańską. Nie chodzi w niej bowiem na ogół o uświęcenie ludzkiego życia, lecz o pokrzyżowanie planu złego demiurga. Nie jest to, ściśle rzecz biorąc, etyka, lecz - jak powiada Hans Jonas - metafizyczna strategia" (K. Dorosz, Przeciw..., s.202.). Podobnie uważa Voegelin zwracając uwagę na pojęcie taktyki jako naczelnego środka realizacji gnostyckiej rzeczywistości: „Tactics are the pathological negation of politics insofar as in principle they do not create order but seek to destroy it" (E. Voegelin, Gnostic..., s. 237).

${ }^{48}$ M. Ruba, dz.cyt., s. 83-86.

${ }^{49}$ Owe kompromisy to zdaniem Voegelina: 1. „Kompromis z ludzką słabością (...) wyrażony przez sakrament chrztu i Wieczerzy Pańskiej, dzięki którym każdy może stać się częścią
} 
starożytnej Grecji i Rzymu. Pomimo tego, gnostycyzm towarzyszył chrześcijaństwu od jego początków aż po średniowiecze, które wydało liczne i dynamiczne ruchy gnostyckie obejmujące wiele obszarów: paulicianów (Syria), bogomiłów (Bałkany), katarów (Francja), waldensów, lollardów (Anglia) oraz husytów (Czechy) ${ }^{50}$.

Można zatem zaryzykować konstatację, iż o ile gnoza starożytna jest radykalną transcendentalizacją pragnień eschatologicznych człowieka, o tyle gnostycyzm nowożytny wyznacza ruch przeciwny: gnoza jest tu radykalną immanentyzacja pragnień zbawienia. Stanowi więc - z chrześcijańskiej perspektywy - drugi skrajny objaw tej samej choroby, wyrosłej z nienawiści do świata i pragnienia ukojenia egzystencjalnych pragnień człowieka wyjścia poza rzeczywistość. Ponieważ sekularyzacja odcina transcendentną „drogę ucieczki”, pozostaje jedynie świat marzeń i snu, skąd pochodzą rozmaite projekty zmiany natury człowieka, czy porządku bytów w celu ustanowienia społeczności doskonałej. W tym wiec sensie „gnoza jako istota nowożytności" jest prostą konsekwencją procesu sekularyzacji chrześcijańskiego przesłania.

M I C H A $€ \quad J$. C Z A R N E C K I

mistycznego ciała Chrystusa”; 2. „Kompromis z władzą pozwolił Kościołowi przetrwać trudności pierwszych wieków, a w dziewiątym stuleciu osiągnął swój szczyt w postaci włączenia funkcji monarchy w porządek charyzmatyczny"; 3. Kompromis z historią, który „opierał się na uznaniu, że Bóg, zanim dał się poznać całemu światu przez Słowo, które stało się Ciałem objawił się poganom w prawie natury i Hebrajczykom w starym zakonie" (E. Voegelin, Lud..., s. 34-35).

${ }^{50}$ Tamże, s. 31-33. 


\section{Man towards the world. Eric Voegelin's modern gnosis and ancient gnosticism - an attempt to compare}

The goal of this article is to present main characteristics of gnosis theory as the essence of modernity as Voegelin described it. Then I try to confront them with the essence of ancient gnosis presented by Hans Jonas, who was one of the leading gnosis researchers. In works Gnosis und spätantiker Geist and Gnosis religion he characterised gnosis positions in the first (I-III) centuries.

Gnosis as the essence of modernity is one of the central problems in Eric Voegelin's political philosophy. A lot of commentators of this conception criticise its wide range and extrapolation of ancient term on analysis of modernity.

Dualism world-human being can be traced in both author's points of view as one of main characteristics of gnosticism (alienation from the world that is evil's root is a part of man's existential situation - this causes man's discontent with his position) along with ascetic or libertinism inclinations and treating man as a source of good (in ancient gnosis theories in the shape of divine spark - pneuma and in modern ones as Übermensch, "will to power" or libido dominandi).

Also on a symbolic level a lot of convergences can be found. Alienation motif and a figure of commander-herald as a positive transfiguration of Promethean motif are also repeated.

Comparing ancient gnosticism with Voegelin's conception one can find important difference - the absence of transcendent matters in modern gnostic symptoms.

While ancient gnosis is a radical transcendentialisation of eschatological human desire, modern gnosticism inversely - gnosis is a radical immanentialisation of desire of salvation. In Christian perspective it is still other extreme symptom of the same disease that is based on the rage against the world and the thirst for meeting existential needs for leaving the reality. Secularisation closes transcendent "way out" and the only thing that is left is world of dreams. Variety of projects that aim at changing human nature or altering great chain of beings in order to create ideal community. In that way "gnosis as an essence of modernity" is a consequence of the secularisation process of Christian message. 